\title{
IMPACTS OF CONSTRUCTION EVENTS \\ ON THE PROJECT EQUITY VALUE OF THE CHANNEL TUNNEL PROJECT
}

\author{
ABRAHAM PARK ${ }^{1}$ and CHEN YU CHANG ${ }^{2}$ \\ ${ }^{1}$ Graziadio School of Business and Management, Pepperdine University, USA \\ ${ }^{2}$ Bartlett School of Construction and Project Management, UCL, UK
}

\begin{abstract}
With the growing strains on public resources, many governments in recent years have turned to the private sector for infrastructure project financing. The special purpose vehicles (SPVs) taking such projects usually have a 2-stage business model: a construction stage followed by an operating stage. However, the project risk in stage 1 is very high, and in most cases, the impacts of specific construction events on project risk and capital cost are unobservable due to lack of informational transparency. Eurotunnel (the Channel Tunnel project) is unique in that the share price data for the entire construction period is publicly available. Based on event study methodology, empirical tests were conducted for several well-documented Eurotunnel construction events to measure and assess the project risk and the impacts of such events on the SPV's equity value. The test results show that: (1) during the construction stage, efforts to better manage the interests and incentives of contractors produce more significant positive impact from investors than efforts for cost containment; (2) during the construction stage, meeting the project deadline is a higher investor priority than containing construction cost; and (3) once the construction phase is complete, the investors' priority then becomes the overall cost and the impact of construction events on the expected returns from investment. Finally, the level of risk and the potential conflicts of interest that arise during the construction phase of a mega infrastructure project are such that turning to IPOs to provide equity capital may not be appropriate.
\end{abstract}

Keywords: Infrastructure development, project finance, project risk measurement, cost of capital, event study.

\section{Introduction}

With the growing strains on public resources, many governments in recent years have turned to the private sector for the provision of infrastructure improvements using a public-private partnership 
(PPP) structure (Harris, 2003). Especially where public financing is lacking or limited, the alternative of project finance with private sector participation has become increasingly popular for highly capitalintensive projects with complex risks, such as transportation and energy projects. Broadly speaking, a public-private partnership (PPP) is an arrangement between public sector and private investors and businesses whereby private sector provides a service under a concession for a defined period on a nonrecourse or limited recourse basis. The rationale behind the PPP arrangement is to combine the resources of the public and private sectors to more efficiently provide public sector infrastructure and services. The PPP paradigm incorporates many common forms of project finance contractual arrangements such as build-operate-transfer (BOT), design-build-operate (DBO), design-build-finance-operate (DBFO) and build-own-operate (BOO). In the UK, the PPP procurement framework gave rise to Private Finance Initiative (PFI), which is a type of project finance where public infrastructure projects are financed with private sector capital through the use of privately funded Special Purpose Vehicles (SPVs). Despite political controversies, various forms of the PPP/PFI scheme have been adopted and deployed around the world for the delivery of large-scale infrastructure projects. Accordingly, a large body of research on PPPs, PFIs, and BOTs have emerged, focusing on diverse topics in construction management and economics. In fact, PPP related research has been growing even more recently (Tang, et al., 2010). These research topics in PPP include: analytical frameworks for PPPs (Ozdoganm and Birgonul, 2000; Ye and Tiong, 2003; Carillo et al., 2006), critical success factors (Li et al., 2005; Tabish and Jha, 2011), contractual arrangements and structures of PPP/PFIs (Ye and Tiong, 2003; Ahadzi and Bowles, 2004; Chowdhury et al, 2011), real options (Liu and Cheah, 2009; Shan et al., 2010), value for money (Akintoye et al., 2003; Henjewele et al., 2011), and even architectural design (Leiringer, 2006; Raisbeck, 2008). Additional studies include geographically-specific applications of various PPP/PFI/BOT schemes in countries such as: Australia (Raisbeck et al., 2010), Malaysia (Lianyu and Tiong, 2005; Abdul-Aziz, 2011); Indonesia (Wibowo, 2005), China (Wang et al., 2000; Chen and Messner, 2005;), Mexico (Vazques and Allen, 2004), UAE (Dulaimi et al., 2010), India (Thomas et al., 2003), and Greece (Roumboutsos and Anagnostopoulos, 2008).

Conceptually, there are many benefits to project finance: a standalone legal and economical project entity for the purpose of financing a single purpose capital asset, access to significant levels of non-recourse or limited recourse debt based on expected cash flows, customizable risk allocations, and asset-specific governance systems. Under the umbrella of appropriate strategic alliances with 
participating governments, project finance with private sector participation allows for the undertaking of many sorely-needed infrastructure projects which otherwise would not be feasible due to size, risk, efficiency and complexity issues. In practice, however, the analytical effort necessary to accomplish proper due diligence with respect to a project's economic viability is vastly underestimated, especially in large infrastructure projects. While Nevitt and Fabozzi (2000:5) state that the main benefit of project financing structure is its ability to generate higher returns by "leveraging the investment to a greater extent than would be possible in a straight commercial financing of the project," high leverage also increases equity risk and expected distress costs, and heightens the importance of accurate future cash flow estimation. According to an extensive study (258 projects) conducted by Aalborg University, in nine out of ten transport infrastructure projects, costs are underestimated by an average of $45 \%$, when compared to actual costs (Flyvbjerg et al., 2003).

On the other hand, Esty (2004) argues that the most important economic motive for using project finance is the reduction of agency conflicts inside project companies (Esty, 2004). This motivation recognizes that large, tangible asset projects with high cash flow potential are prone to costly agency conflicts that destroy value (Jensen and Meckling, 1976), and the creation of asset-specific governance system of project finance companies can address the conflicts between ownership and control. Furthermore, various types of asset specificity can lead to costly agency conflicts known as "hold-up" (Williamson, 1985), including in construction projects where construction clients become vulnerable at post-contract stage due a change in the initial requirements coupled with an incomplete contract (Chang and Ive, 2007). Thus, according to Esty (2004), by creating an asset-specific governance system, the project finance structure (extensive contracting, concentrated equity and debt ownership, a separate legal entity, and high leverage) can reduce the agency cost between ownership and management, lessen cash flow problems, and avert opportunistic behaviours.

While various economic motivations underlie each project financing company, the invariable aspect to all project financing arrangements is in the use of a series of contracts to define, allocate, and manage the risk/reward system among the stakeholders of the project (Finnerty, 1996). Project finance is often referred to as 'contract finance' because a typical transaction can involve 15 parties united in a vertical chain through 40 or more contractual agreements (Esty and Christoy, 2002). In fact, the contractual arrangements are at the heart of the credit support required by the lenders to provide for project financing. Because the contracts define and allocate the cash flows among the various 
stakeholders and the only recourse for debt repayment is from these cash flows, the lenders are heavily reliant upon the contracts to determine their risk exposure. A BOOT project financing structure typically includes contracts with construction, product off-take, raw material, supply, operation, maintenance, and investors. A successful project financing therefore depends upon the strength and the completeness of these contractual agreements. Lenders typically begin their cash flow estimation from the projected costs and timings of construction, followed by projected operation and maintenance costs, and then projected revenues to be generated by the project. Since expectations of cash flows are at the heart of project finance, extensive and accurate feasibility analyses and risk assessment/measurement are critical in determining the project's economic viability. Often, not only are the length and cost of delays underestimated, the revenue expectations are overly optimistic, and changes in project specifications and designs are inadequately taken into account. Some of the biggest sources of risk are delays in construction, delays in projected revenue flow, technical failure, poor management, and regulatory and design changes (Beidleman et al., 1990; Bordoli and Baldwin, 1998; Cox et al., 1999).

Xenidis and Angelides (2005) provide a comprehensive list of 27 financial risks for a BOT project. In particular, the main sources of financial risk in major transportation infrastructure project are cost overruns (especially in the construction phase), increased financing costs due to delays, and lower than expected revenues (Flyvbjerg et al., 2003). Schaufelberger and Wipadapisut (2003) include cost of capital in the construction financial risk category while they consider unanticipated construction cost overruns as operational risk. According to Merna et al., (2007), risk is the possibility of unexpected event occurrences which impact economic returns; therefore, project finance must be structured such that risk, which influence the amount, timing and availability of funds for project financing, can be accurately allocated to secure and increase the financial viability of a project (Merna et al., 2007). At any time during the life of the project, events that affect the risk profile of the project, therefore, have a direct impact on the overall value and the financial viability of the project. From the lenders perspective, unexpected events may jeopardize the completion of the project and timely repayment of debt, which is substantially larger in proportion than equity investment in project finance companies. As such the lenders in project finance are particularly interested in how project risks are structured, allocated, and managed (Huseby and Skogen, 1992).

Accordingly, the most crucial element to successful project finance is the effective management of various project risks. The main elements of project risk management include the identification, the 
measurement/assessment, and the process of prioritizing and responding to various project risks (Thomas et al., 2006). Among these elements, risk measurement/assessment is the most difficult task, which involves evaluation of the probability of occurrence of risk events and their impact on the project (Thomas et al., 2006). For international construction projects, past research studies have proposed various approaches for project risk assessment/measurement, including: decision analysis (Jeljeli and Russell, 1995; Mulholland and Christian, 1999; Han and Diekmann, 2001), fuzzy set analysis (Jablonowski, 1994; Tah and Carr, 2000), simulation and sensitivity analysis (Woodward, 1995; Songer, et al., 1997; Ye and Tiong, 2000), and analytical hierarchy process analysis (Mustafa and Al-Bahar, 1991; Hastak and Shaked, 2000). In most of the infrastructure BOT projects, simulation and sensitivity analysis are used for technical and financial risk assessment; however, risk measurement is often constrained by the nonavailability of past information on impact of important risk factors, including events which affect the risk profile of BOT projects (Thomas et al, 2006).

To date, although at least nine empirical studies on PPP risks have been written, all of these studies are based on surveys and case studies (Li et al., 2005a; Shen et al., 2006; Akintoye et al., 1998; Li and Tiong, 1999; Schaufelberger and Wipadapisut, 2003; Yeo and Tiong, 2000; Zayed and Chang, 2002; Lam and Chow, 1999; Abednego and Ogunlana, 2006). The goal of this paper is to fill the gap in empirical research concerning the measurement and assessment of project risk factors and to clarify the dynamics of project risk by providing evidence on the impact of construction events on the cost of capital and the equity value of the project finance company.

Theoretically, the amount and the timing of expected cash flows as well as the relevant risks for the on-going project should be reflected in the project value from start to finish. In corporate finance, a firm is viewed as a portfolio of on-going projects; thus, in an efficient market, the ever-changing stock price of the firm reflects the changes in expected free cash flows, the systematic and unsystematic risks, and the capital structure of the project portfolio based on all publicly available information. Because project finance involves single project companies, it could potentially provide researchers with valuable insights into the constantly evolving risk profile of projects as well as the financial impacts of various events on the project equity value. However, the challenge for researchers has consistently been the lack of informational transparency.

This lack of transparency stems primarily from concentrated ownership structure of project finance companies. Typically, project companies have a few equity shareholders as sponsors with a 
syndicate of banks as debt investors (Esty, 2004). As such, whenever events that affect the expected cash flows and risk of a project occur, the impact of such events on the project value remains undisclosed, except among the few equity and debt investors. For example, infrastructure projects are often established through an award by a government agency to a private sector company of a concession to build and operate for a fixed number of years. Typically, this build-own-operate-transfer (BOOT) approach involves a consortia of equity investors (interested party investors such as construction contractors, equipment suppliers, and utility operators), a syndicate of bank lenders, and a group of contractor, subcontractors, and suppliers that are linked through a series of legal contracts that allocate the risk and rewards during each phase of the project (development, construction, and operation). Therefore, each event that occurs during each project phase can have distinct impact on the expected cash flows, project risk, and the overall project value. A better understanding of the quantitative impact of various types of risks that are faced by project finance companies can help to reduce the gap between actual and forecasted project estimates.

From the perspective of project finance research, the Channel Tunnel project is unique for at least three reasons: first, according to Kleimeier and Megginson (2000), the Eurotunnel project has the distinction of being both the largest and the second largest project financing in history due to two financing steps of the project in 1987 and 1990; second, unlike most other project finance companies, Eurotunnel's equity capital base included funds raised through an initial public offering, and the historical stock price data is available from the beginning and through the entire construction phase of the project; and third, during the period of 1990 to 1994, Eurotunnel faced several unexpected public disputes and construction delays with its contractor, Transmanche-Link (TML). Consequently, even though several years have passed since the completion of the project, Eurotunnel is still relevant in the field of project finance because Eurotunnel's share price data availability allows for a unique opportunity to quantitatively measure the impact of risk-affecting construction events on the cost of capital and the equity value of the project finance company.

As seen from the perspective of transaction cost economics (TCE), during the contracting period, one party may be susceptible to the opportunistic exploitation of the other party in the presence of appropriable quasi rent. As some unforeseen events may drift the contract out of the governable range, intense disputes may follow for the allocation of burden of the unexpected costs. Since the costs involved in dispute resolution vary with governance structures (Williamson, 1985), aligning governance structures 
with transaction attributes would lead to efficiency improvement. Empirically, the predictions of TCE are normally tested on the basis of its reduced form (i.e., the statistical significance of the effect of a transaction attribute on the choice of governance structures) (Mastenet al., 1991). Among the vast volume of TCE empirical studies (Macher and Richman, 2008; Lafontaine and Slade, 2007), researchers rarely examined the impact of disputes directly in the context of a project due to the fact that the measurement of the spill-over impact of disputes on the organisation requires comprehensive data, which are either not collected or kept confidential in practice. Eurotunnel is a one project company, and given the efficient market hypothesis (Fabozzi et al., 2012), its share prices should be fully reflective of the financial impact of construction events (cost overruns and delays), giving researchers a rare opportunity to investigate the costliness of construction disputes based on market evaluations.

This paper is organized as follows: the second section provides an overview of the Channel Tunnel project; the third section reviews the data and the event study methodology which is used to measure the impact of construction events on the project equity value and the project cost of capital; the fourth section analyzes the results; the fifth section discusses the implications from the study, and the last section provides conclusions and limitations.

\section{The Channel Tunnel project}

The Channel Tunnel project is a standard Build-Own-Operate-Transfer (BOOT) project. Established in1986 to build and operate a tunnel under a 55 year concession from the French and UK governments, Eurotunnel (the project company) was formed as a partnership between France Manche S.A. (France) and The Channel Tunnel Group Limited (UK). This partnership was a subsidiary of Eurotunnel S.A. (France) and Eurotunnel PLC (UK), while Eurotunnel Finance S.A. (France) and Eurotunnel Limited (UK) were also subsidiaries with responsibilities of financing the project. Eurotunnel Developments S.A. (France) and Eurotunnel Developments Limited (UK) were also formed as subsidiaries to enter into joint venture agreements with third parties for the purposes of developing properties and businesses outside of, but resulting from, the Eurotunnel system. The original capital of $£ 47$ million (Equity Offering 1 ) for Eurotunnel was provided by the promoters, which included 5 banks (National Westminster, Midland, Credit Lyonnais, Banque Nationale de Paris, and Banque Indo-Suez), and a 10-company consortium, Transmanche-Link (TML), which included five UK contractors (Balfour Beatty, Costain, Tarmac, Taylor Woodrow and Wimpey) and five French contractors (Bouygues, Demez, SAE, SGE and Spie Batignolles). 
In 1986, TML was chosen as the contractor for the project, and when the contracts for construction were signed in August of 1986 between Eurotunnel and TML, TML was in fact the majority shareholder of Eurotunnel. At this point, the design of the tunnel was not yet complete, and changes were still coming to comply with the instructions issued by the Intergovernmental Commission (IGC).Therefore, this project from the start was overshadowed by conflict of interest and uncertainty in design requirements which plagued the project throughout the entire construction phase and beyond.

[Insert Figure 1 here]

In September of 1986, Eurotunnel was recapitalized with additional £206 million from institutional investors (Equity Offering 2). In November and December of 1987, a syndicate of 198 banks worldwide signed a credit agreement for $£ 5$ billion, while equity of $£ 770$ million (Equity Offering 3 ) was raised through IPO in both the British and French stock markets. In November of 1990, additional public offering was issued in the amount of $£ 568$ million (Equity Offering 4) while additional $£ 1.8$ billion of bank credit facilities were agreed upon. Due to the banks' equity investment requirements in the credit agreement, the capital structure of the project remained relatively constant at approximately $20 \%$ equity and $80 \%$ debt for the entire duration of the construction.

The construction work was governed by two types of contracts: the tunnelling was based on a cost-plus contract while the fitting out of terminals was based on a lump-sum contract. When the tunnelling began, the geological conditions were revealed to be worse than expected and the tunnelling speed was far slower than originally anticipated. By August of 1988, TML missed two milestones and faced huge financial penalties. With the cost estimate continuing to rise with time, contractors had started funding work on the project themselves, and eventually, TML was forced to file claims for $£ 47$ million of extra payments and 11 months of time extension.

According to the arbitration clause of the agreed construction contract, disputes were to be brought to a panel of disinterested experts with a right to an appeal to the International Chamber of Commerce. Although according to the contract, rulings had to be made within 90 days; TML had to continue to progress on the tunnelling while the arbitration case was being decided. TML was in a bind because without the immediate infusion of extra payments, it was facing bankruptcy.

Eurotunnel was in no better position than TML as equity funds were being drained at a rapid pace. The credit agreement with the banks stipulated that the first drawdown on loans could be made only 
if certain conditions were met -namely, cover ratio, specified cost and completion time indicated in the construction contract. If the drawdown on the loan were not approved, Eurotunnel faced a grave risk of default. Some forceful negotiations by the banks resulted in an agreement between Eurotunnel and TML in January of 1989 , which granted a 1 month extension to TML and a fresh incentive package for meeting milestones and completing on time.

Although the relationship improved, the two sides came head to head again in late 1989. With the growing speculation of cost overruns, Eurotunnel blamed TML for the original cost estimates that formed the basis for the winning bid when the contract was signed in 1986 when TML was the major shareholder of Eurotunnel. On the other hand, TML countered the blame by claiming that the cost overruns were mainly due to subsequently mandated design changes rather than problems with the original estimates.

This public dispute (Event \#1for the purpose of this paper) came to an agreement in January of 1990. This revised deal included: (1) Increased total construction cost from $£ 5$ billion to £7.2 billion; (2) TML to bear $30 \%$ of all cost overruns, rather than $6 \%$ as originally agreed; and (3) a stronger incentive upon TML to complete the project on time by giving more generous bonuses and more severe penalties.

The repaired relationship resulted in a rapid progress of the project. In 1990, Eurotunnel was successful in raising $£ 1.8$ billion of additional funds from the syndicate of banks, a rights issue to the shareholders, and the European Coal and Steel community. However, the next big dispute was waiting around the corner due to two significant external uncertainties related to the lump-sum fit-out contract. The first uncertainty emerged when the IGC demanded a tighter safety measure by requiring a larger train door than the original design that TML had based on. Although this added requirement appeared minor, this change resulted in considerable redesign, delay, and added costs in delivery of the rail cars, which resulted in expensive delays to the tunnel service. The second uncertainty was based on changes in potential capacity and demands from the users of the Tunnel that required additional alterations to fixtures such as cooling and signalling systems. Both of these two changes resulted in profound cost impact on the lump-sum fit-out contract and a bitter dispute between the parties. TML's contention to the arbitration panel consisted mainly of two issues: first, that Eurotunnel should be responsible for cost increases and time delay for intervening in design changes in breach of contract; and second, that TML should be granted an extension of 55 weeks to install the equipment. 
In February of 1991, the arbitration panel ruled (Event \#2) the first issue on TML's favour, indicating that Eurotunnel should be responsible for cost increases. However, the panel refused to grant TML's request for a time extension of 55 weeks. This ruling meant that Eurotunnel faced higher cost claims from TML (as indicated in Eurotunnel's annual report in May of 1991).

By October of 1991, hostilities again broke out between the parties when the progress payments from Eurotunnel to TML did not reflect the cost increases and TML was facing negative cash flows. With over $£ 1.2$ billion at stake, TML was determined to make Eurotunnel responsible for their extra costs, while Eurotunnel was exercising its discretion on the amount of cash progress payments to counter what appeared to be a go-slow strategy of TML.TML threatened to suspend work on cooling systems if Eurotunnel failed to meet certain conditions and the matter was taken to the Disputes Panel. In March of 1992, the panel ruled (Event \#3) in favour of TML, and ordered an additional $£ 50$ million (from original $£ 25$ million) to be paid to TML each month.

While Eurotunnel had to comply with the ruling, they also took the matter to the Court of Appeals. Because the amount of money at stake was so large, both parties were aware that this issue was going to be a lengthy battle. What neither party could afford, however, was a major delay or suspension of work. After the initial ruling of March 1992, the biggest issue that was to emerge for both parties was the potential impact of delayed opening as a result of this lengthy battle. In October of 1992, the London Evening Standard published an article indicating a sharply lower (by 28\%) revenue forecasts for the first year due to missing of the peak summer season as a result of the delay (Event \#4).

Eurotunnel and TML continued to battle in court, and the final verdict by the International Chamber of Commerce was reached in March of 1993 (Event \#5). The ruling was that the issues had to be resolved claim by claim, and the two parties were back to the original point of having to settle by outof-court negotiations. The ICC prohibited a global settlement ruling, and it indicated a tedious and costly process of itemising each claim to recover payments. With over $£ 1$ billion still up in the air, the project was faced with worries over additional delays. For Eurotunnel, slow progress meant missing the peak 1993 summer holiday season, which was estimated at $£ 100$ million per month.

With the entire project in crisis with, the syndicate of banks had to intervene. The prolonged dispute saw a glimmer of hope when a protocol of agreement was reached in July 1993 (Event \#6). According to this agreement, TML was to receive an interim payment of $£ 235 \mathrm{~m}$ in exchange for its commitment on setting a hand-over date of December $1^{\text {st }}, 1993$. This agreement gave TML enough cash 
to finish the project and was a first step in the resolution of the dispute along with a definite hand-over date which put a limit on the delay.

TML met this target, and around the time when the project was handed over to Eurotunnel, TML made a final claim submission seeking $£ 1.98$ billion, which was $35 \%$ more than what TML had previously submitted as a global claim. The resolution of this drawn out dispute was reached in April 1994 (Event \#7) with Eurotunnel having to pay TML £1.14 billion in cash. The tunnel was finally opened officially on May $6^{\text {th }}, 1994,12$ months after the originally planned date.

\section{Research design, methodology and data description}

According to finance theory, when a specific event occurs during the construction phase of a project which affects the risk level of equity investors, there should be a significant impact on the project's market equity value as a result of the change in the cost of equity. For most projects that are structured as SPVs, the impacts of these events on the project's market value are unobservable. However, since the Eurotunnel project is unique in that the market price data for the entire construction period are available, we can use the event study methodology to test and observe the impact of occurrences of specific construction events on the project equity value. Furthermore, according to Campbell et al. (2001), rolling standard deviation of share prices can be used as a volatility measure to graphically observe the changes in the project's equity risk level. Specifically, we look for changes in the direction of the rolling standard deviation as a result of the impact of the construction events. Although the general risk level of the equity investment should decrease as the project progresses during the construction phase toward the operational phase, occurrences of specific events should, in theory, alter the risk level as measured by rolling standard deviation.

Our hypothesis is that when events occur which impact the SPV's risk level either positively or negatively, the impacts should be observable through significant abnormal returns as well as through changes in the direction of the volatility measure. The following subsections describe the event study methodology.

\section{(1) Event Study Step 1: Identification of Events}

An event study is a widely used methodology in the fields of economics and finance for measuring the impact in share prices as a result of an announcement event. Brown and Warner (1985), 
Mackinlay (1997), and Binder (1998) provide for comprehensive descriptions of the procedures in the event study methodology.

The first task of conducting an event study is to identify the event(s) of interest. Due the public nature of the project, the news surrounding the various disputes and resolutions of Eurotunnel construction as described in the previous section were covered extensively by the media. We reviewed and identified from LexisNexis database the following seven important announcement events during the Eurotunnel construction period of 1988 to 1994 :

\section{[Insert Table 1 here]}

As indicated in the last column of Table 1, these significant announcements were numbered chronologically from Dispute \#1 to Dispute \#7.

\section{(2) Event Study Step 2: Event Window}

The second step in event study methodology is to define the event window - period over which the share prices of the firm involved in the event are examined. When announcement events are involved, it is customary to define the event window as several days before and after the day of the announcement. The reason for the examination of days surrounding the event date is to capture the price effects of information leakage before the public announcement and the effects immediately following the event. As in Mackinlay (1997), we identified 15 days before and after the event date as the event window for our study.

\section{(3) Event Study Step 3: Estimation Window}

The third step in event methodology is to calculate the normal return over the event window. The normal return is defined as the expected return of the firm without the consideration of the event taking place. In other words, normal return calculation measures the benchmark return over the event window without considering the event. To perform this task, several different financial models can be used, with the return estimation based on the share price data over a period prior to the event window known as the estimation window. Following Mackinlay (1997), we defined our estimation window as 250 days before the event window, and selected the market model as our benchmark financial model to calculate normal returns. We used daily share price data of Eurotunnel to calculate daily returns. 


\section{(4) Event Study Step 4: Measuring Normal Returns}

The fourth step is the calculation of normal returns. The literature on event studies shows ample support for the effectiveness and the popularity of the market model. The market model is a statistical model that relates the return of any given security to the return of the market portfolio. For any security $i$, the market model assumes that the returns are given by:

$$
\begin{aligned}
& R_{i t}=\alpha_{i}+\beta_{i} R_{m t}+\varepsilon_{i t}, \text { where } \\
& E\left(\varepsilon_{i t}=0\right) \text { and } \operatorname{Var}\left(\varepsilon_{i t}\right)=\sigma_{\varepsilon i}^{2}
\end{aligned}
$$

In this model, $R_{i t}$ and $R_{m t}$ are the returns on security $i$ and the market portfolio, respectively, over period t. $\quad \varepsilon_{i t}$ is the zero mean disturbance term and $\sigma_{\varepsilon i}^{2}$ is the variance of the disturbance term. By regressing the above equation over the estimation window, the coefficients $\alpha_{i}, \beta_{i}$ for the security $i$ can be calculated. Using these parameters, the normal return for security $i$ over the event window can be estimated using the equation $\alpha_{i}+\beta_{i} R_{m t}$.

Although the market model has proven to be effective, other researchers have suggested several different models as better candidates for calculating normal returns: Capital Asset Pricing Model (CAPM), Intertemporal Capital Asset Pricing Model (ICAPM), and Asset Pricing Theory (APT).

CAPM is a classic finance model used to estimate security returns. This theory demonstrates that, in equilibrium, the expected return of a given stock is determined by its covariance with the market portfolio (Sharpe, 1964; Lintner, 1965), i.e.,

$$
R_{i t}=R_{f}+\alpha_{i}+\left(R_{m t}-R_{f}\right) \beta_{i}+\varepsilon_{i t}
$$

where $R_{i t}, R_{m t}$ and $R_{f}$ are the returns on security $i$, the market portfolio at the period $\mathrm{t}$, and risk free assets, respectively. $\varepsilon_{i t}$ is the zero mean disturbance term and running a regression on the equation can yield coefficients $\alpha_{i}, \beta_{i}$ by which the normal return can be estimated.

Intertemporal Capital Asset Pricing Model (ICAPM) was put forth by Merton (1973) as an alternative specification to CAPM. According to ICAPM, the company's return is influenced not only by 
returns of market portfolio, but also by other investment portfolios' returns. ICAPM can be described as follows:

$$
R_{i}-R_{f}=\alpha_{i}+\beta_{1 i}\left(R_{m}-R_{f}\right)+\beta_{2 i}\left(R_{N}-R_{f}\right)+\varepsilon_{i}
$$

where $R_{N}$ is the expected return on the "zero-beta" portfolio, $R_{i}$ is the return of any stock portfolio, and $R_{f}$ is the risk-free portfolio's return, while $R_{N}$ must be bigger than $R_{f}$. According to Merton (1973), a long-term bond portfolio may be used as a proxy for "zero-beta" portfolio. Therefore, the normal return for security $i$ at time $t$ can be specified as:

$$
R_{f}+\alpha_{i}+\beta_{1 i}\left(R_{m}-R_{f}\right)+\beta_{2 i}\left(R_{N}-R_{f}\right)
$$

Asset Pricing Theory (APT) is another model for determining normal return. In this model, the expected return of a given asset is a linear combination of multiple risk factors (Ross, 1976), including macroeconomic variables (Chen et al., 1986). APT model can be described as follows:

$$
R_{i}=\alpha_{1 i}+\alpha_{2 i} F_{1}+\ldots+\alpha_{n i} F_{n}+\varepsilon_{i}
$$

where $R_{i}$ is the return of any stock or stock portfolio $i, F_{n}$ is the mean zero $\mathrm{n}^{\text {th }}$ factor common to the results of all assets, $\alpha_{n i}$ is the sensitivity of the $i^{\text {th }}$ asset's returns to the $\mathrm{n}^{\text {th }}$ factor, while $\varepsilon_{i}$ is a random zero mean noise term for the $i^{\text {th }}$ asset. In particular, Chen et al., (1986) suggest five important macroeconomic factors as appropriate for inclusion in the APT model: (1) monthly growth of industrial production, (2) change in expected inflation, (3) unexpected inflation, (4) risk premium, and (5) term structure.

In our study, we tested all four models to calculate normal returns. The share price information was gathered from DataStream; FTSE All- Shares Index was used to calculate the market returns; UK 10 year government bond yields were used as long-term bond portfolio for ICAPM model; FTSE transportation industry index was used as industrial portfolio; the general inflation rate, transportation industry inflation rate, unemployment rate and term structure of the interest rates (the difference between long and short term government bond rates) were used as the macroeconomic variables in the APT model.

For each event, we calculated normal returns over the estimation window of each event, and the estimated parameters and coefficients from each model were used to estimate the daily normal returns over the event window. 


\section{(5) Event Study Step 5: Measuring Abnormal Returns}

The fifth step and the ultimate goal of event study is to measure the impact of the event by calculating the abnormal return over the event window. Abnormal return $\left(A R_{\tau}\right)$ can be defined as:

$$
A R_{\tau}=R_{\tau}-E\left(R_{\tau}\right)
$$

where $R_{\tau}$ and $E\left(R_{\tau}\right)$ are actual return and normal returns respectively for the event date $\tau$. In other words, the abnormal return is the actual return of the security minus the expected normal return of the firm over each day of the event window that was calculated in step three. Once the abnormal returns over the event window are calculated, the next step is to design the testing framework for the abnormal returns, including techniques for aggregating the individual abnormal returns over the event window.

\section{(6) Event Study Step 6: Testing for Significance of Cumulative Abnormal Returns}

In the sixth step, to test for the significance of the abnormal returns, the daily abnormal returns over the event window are aggregated as cumulative abnormal returns and tested against a null hypothesis. In a single firm scenario, the cumulate abnormal return $\operatorname{CAR}\left(\tau_{1}, \tau_{2}\right)$ occurring in the event window $\left[\tau_{1}, \tau_{2}\right]$ can be calculated by simply adding up the abnormal returns over the event window:

$$
\operatorname{CAR}\left(\tau_{1}, \tau_{2}\right)=\sum_{\tau=\tau_{1}}^{\tau_{2}} A R_{\tau}
$$

Then, the distribution of the cumulative abnormal return under $H_{0}$ is:

$$
\operatorname{CAR}_{i}\left(\tau_{1}, \tau_{2}\right) \approx N\left(0, \sigma_{i}^{2}\left(\tau_{1}, \tau_{2}\right)\right)
$$

Under the null hypothesis that the abnormal returns are zero, the cumulative abnormal returns can be tested for significance using the sample variance measure of $\sigma_{\varepsilon i}^{2}$ from the market model regression (Mackinlay 1997). If the cumulative abnormal returns are significantly different from zero, we can reasonably conclude that the event has significant impact on the value of the firm.

\section{(7) Event Study Step 7: Analysis}

The seventh and the final step in event study is the analysis of the empirical results, leading to insights into the sources and causes of the event under study.

\section{Results}


The following table shows the results from the event study of seven important announcement events during the construction period of 1988 to 1994 for Eurotunnel based on all four models:

[Insert Table 2 here]

All four models showed consistency in producing significant results for all seven events. Both the market model and the CAPM showed almost identical results, while all four models produced the same order of ranking for the degree of impact among the seven events. The signs were also consistent for all four models: events 1, 2 and 6 had positive impacts for the SPV's equity value, while events 3, 4, 5, and 7 had negative impacts.

The event Deal Cuts Risk of Channel Tunnel Overrun (Event \#1) was a public dispute that came to an agreement on January $12^{\text {th }}$ of 1990 . This event produced the highest positive cumulative abnormal return. The agreement contained three main components: (1) increase in total construction cost from $£ 5$ billion to $£ 7.2$ billion; (2) TML to bear $30 \%$ of all cost overruns, rather than $6 \%$ as originally agreed; and (3) a stronger incentive upon TML to complete the project on time through bonuses and more severe penalties. Even though the increase in total construction cost is a negative factor, the better alignment of incentives by TML clearly outweighed this negative factor. Some of the increase in construction cost must have been anticipated, but the sign of a greater certainty of construction completion produced an overwhelmingly positive impact on the returns. This event shows the importance of having a construction contract that focuses on the alignment of interest rather than just a low cost. This result also shows that the concept of transferring construction risk to contractors through a set of legal contracts may not be so straightforward in infrastructure projects with highly specific assets. In particular, deals that focus on the management and alignment of interests in a dynamic way, especially during the initial stages of construction, could result in superior results.

The event Eurotunnel Costs Set to Soar After Ruling (Event \#2) was a ruling from the arbitration panel on February $10^{\text {th }}$ of 1991 concerning two main issues. The first issue was a ruling in favour of the contractor, TML, that Eurotunnel was responsible for cost increases (as indicated in Eurotunnel's annual report in May of 1991). The second issue was a ruling in favour of Eurotunnel, indicating that TML was denied a time extension of 55 weeks. Surprisingly, this ruling produced the second highest positive cumulative abnormal return. This result suggests that construction delay was a bigger risk issue to equity investors at this junction than potential cost increases. Even though the increase in cost would result in a 
lower IRR, it appears that a greater certainty of project completion is a bigger issue for equity investors, especially at the beginning of the construction phase. The implication is that the reduction of overall project completion risk as a result of achieving a more definite completion deadline is a more important factor to equity investors than a limited increase in the level of construction cost.

In the event Dispute Panel Rules Eurotunnel Should Treble Monthly Payment to Meet TML's Expenses, 30 March 1992 (Event \#3), Eurotunnel was ordered to treble its monthly interim funding payments to TML from $£ 25 \mathrm{~m}$ to $£ 75 \mathrm{~m}$. This event produced the lowest negative impact and the third highest absolute impact among all the events. In October of 1991, the progress payments from Eurotunnel to TML did not reflect the cost increases and TML faced negative cash flows and threatened to suspend work due to negative cash flows. The matter was taken to the Disputes Panel and in March of 1992, the panel ruled in favour of TML, and ordered an additional $£ 50$ million (from original $£ 25$ million) to be paid to TML each month. This event had a double negative impact for Eurotunnel: first, the negative cash flows by TML were a serious threat to the overall project completion and second, the additional payments represented over $£ 1.2$ billion for Eurotunnel.

The event Opening Date Delay Adds to Worries (Event \#4) had two main negative implications for Eurotunnel. After the previous ruling on the interim payments, Eurotunnel took the matter to the Court of Appeals, which the investors knew was going to be a lengthy legal battle with a potential for a major delay or suspension of work. On October $5^{\text {th }}$ of 1992, the London Evening Standard published an article indicating two main negative news for Eurotunnel investors: first, a delay in the construction completion date and second, a sharply lower revenue forecasts for the first year as a result of Eurotunnel missing the summer peak season. This news produced a negative cumulative abnormal return.

The event 'Ibn Shortfall' as Tunnel Hits New Delay, 29 March 1993 (Dispute \#5) produced a significant negative cumulative abnormal return as a result of the final verdict by the International Chamber of Commerce that the disputed issues had to be resolved claim by claim. This ruling essentially represented a tedious and costly process of itemising each claim to recover payments which meant the project was faced with worries over additional delays. Once again, a potential delay resulted in a strong negative impact on the returns.

On the other hand, a protocol of agreement that was reached in July 1993 (Dispute \#6) produced positive abnormal returns primarily because of TML's commitment on setting a hand-over date of 1 
December 1993. This agreement gave a definite hand-over date which put a limit on the construction delay.

Finally, the resolution of the drawn out dispute regarding payments was reached in April 1994 (Dispute \#7). TML had made a final claim submission seeking $£ 1.980$ billion, but both sides reached a final agreement of Eurotunnel having to pay TML $£ 1.14$ billion in cash. This event produced the second lowest negative cumulative abnormal return. Once the construction was finally complete, the issue turned to the final cost of construction, and the ruling that Eurotunnel, rather than the contractor, had to bear the cost produced a significantly negative reaction from the equity investors.

To further confirm the impact of various dispute events on the risk of project equity value during the construction phase of a project, we used the daily price data to construct a graph depicting the time variation in volatility of Eurotunnel. The following graph shows the 12 month rolling standard deviation as a volatility measure described in Campbell et al. (2001), with vertical bars indicating 7 events and event windows discussed in this paper:

\section{[Insert Figure 2 here]}

The result from the above volatility study shows a graphical trend of the stand-alone risk of equity investments during the construction phase. The seven events are indicated using vertical bars in Figure 1. Theoretically, though not necessarily, as the project progresses the risk level of project equity value should steadily decrease, until the construction is complete and the operational phase begins. However, when significant construction events affect the risk level of the project, the volatility trend should also reflect the impacts of those events in addition to the abnormal returns indicated by the above event study. The basic assumption in this type of graphical study is that the analysed events provide significant new information to market participants such that the events greatly alter the expectations of the market participants. Specifically, we discovered a directional change in the volatility trend as measured by 12 month rolling standard deviation in each of the occurrences of the 7 events covered in this study.

This result is generally consistent with theory, that significant dispute events impact the risk level of equity investments. However, one limitation of a graphical trend study of volatility as measured by a rolling 12 month standard deviation is that it utilizes equally weighted returns which do not show increasing sensitivity to the returns that are closer to the actual event. Furthermore, because of the 12 month rolling nature of the volatility measure, there should be a time lag between the actual event and the 
resulting impact on the rolling standard deviation. The only way a directional change can be observed at or near the event is if the change in volatility caused by the event is so significant that it impacts the rolling standard deviation immediately. Apart from the observable directional changes, this type of graphical volatility study is limited in that it cannot provide further insights into the degree of impact based on the significance of directional changes appearing on the graph.

\section{Discussion}

It is a common practice in project financing that the sources of finance change over the project's life cycle to match the evolving pattern of risks and incentives. During the constructional phase, the expenditures are financed with sponsor equity and bank loans. Because construction is subject to significant uncertainty and risk, there is plenty of room for moral hazard, and it is appropriate that that the banks perform a monitoring role at this stage. The fact that the initial equity sponsors in project financing are often interested parties (operators or contractors) adds to the responsibility of the banks to provide tight control over the project company and the building contractor's behaviour. One of the ways a project is monitored by the banks is to require a certain level of debt/equity ratio with a certain percentage of the SPV to be financed by the sponsors (approximately 20-30\%) who are often the contractors and operators. This requirement ensures alignment of interest between the lenders and the sponsors.

In the case of Eurotunnel, the debt to equity ratio for Eurotunnel remained stable at approximately $80 \%$ to $20 \%$. The primary reason for the IPOs in both 1987 and 1990 was due to the lenders' requirement for maintaining debt to equity ratio (total equity was approximately $£ 1.6$ billion while total debt was approximately $£ 6.8$ billion). However, unlike other projects, in the case of Eurotunnel the equity ownership percentage of the original sponsors of project equity (who were also the contractors for the construction) became quickly diluted when additional equity was raised through IPO rather than from the original sponsors. This resulted in the majority of the sponsor equity for the construction phase of Eurotunnel coming from passive, small time investors from the IPO. This dilution also resulted in the original sponsors to shift their loyalty and incentives towards the contractor side rather than the SPV (Eurotunnel) side. This shift left the equity investors from the IPO to be in an unfairly vulnerable position, and the cost of equity was in actuality much higher than originally presented.

The revenue projections for Eurotunnel were included in the 1987 prospectus, as well as Rights Issue documents in 1990 and 1994. The projections were sharply lower in 1994, but there was no 
noticeable difference between 1987 and 1990 projections. The estimated IRRs included in the prospectus and the 1990 Rights Issue were in the range of $17-18 \%$ considering long term investment horizon. However, this type of hurdle rate should only have been appropriate for investors in the operational phase of the project rather than in the construction phase, which contains significant uncertainty and higher risk compared to the operational phase. Considering that there were no dividends promised during the construction period and limitations to revenue growth, the government's position to support the IPO of Eurotunnel to individual investors during the construction period seems unwarranted.

\section{Conclusion and Limitations}

The main obstacle of research in the area of private sector participation in infrastructure project financing has been the lack of available data to properly analyse the risk and return characteristics of investments during the life cycle of the project (Bitsch et al., 2010). The SPV taking the project usually has a 2 stage business model: a construction stage followed by an operating stage. However, the project risk in stage 1 is very high, and the risk return characteristics for investment analysis are fundamentally different from those of stage 2. Using the event study methodology, quantitative measurements were performed on the impacts of specific construction events on the risk, the cost of capital, and the project equity value of a major infrastructure construction project. The empirical results produced a few interesting results which provide some clarity as to the dynamics of project risk during the construction phase of a PPP/PFI project: (1) during the construction stage, efforts to better manage the interests and incentives of contractors produce more significant positive impact from investors than efforts for cost containment; (2) during the construction stage, meeting the project deadline is a higher investor priority than containing construction cost; and (3) once the project is finished, the investors' focus then turns to the overall cost and the expected returns from investment (adjustments to IRR and investment horizon). Additional volatility trend study using 12 month rolling standard deviations confirmed these findings, while acknowledging the interpretive and procedural limitations of such graphical trend studies.

Collectively, these findings indicate that construction delay poses greater risk to project equity investors at the beginning of the construction phase than cost overruns. A possible explanation is that due to the high leverage structure of project finance companies (high level of debt compared to equity), the potential accumulation of finance charges due to delay poses greater financial risk than limited cost overruns. Although this explanation cannot be verified from this study, at least two practical implications 
can be extracted: one, having a construction contract that focuses on the alignment of interest is critical for project risk management and economic viability of the project; and two, the concept of transferring construction risk to contractors through a set of legal contracts may not be so straightforward in infrastructure projects with highly specific assets.

Conceptually, the Eurotunnel case has revealed that raising equity capital through IPO during the construction phase can significantly affect the agency structure and the interest alignment among the participants in the project. Unlike in other project finance cases, in Eurotunnel the equity ownership percentage of the original sponsors became diluted by passive investors from the IPO. As the contractors were also the original sponsors for Eurotunnel, this dilution left the equity investors from the IPO in a vulnerable position. Accordingly, this ownership dilution makes the cost of equity for IPO investors in project finance to be significantly higher than equity investors in non-IPO project finance cases. For this reason, the level of risk and the potential conflicts of interest that arise during the construction phase of a mega infrastructure project are such that turning to IPOs to provide equity capital may not be appropriate. Moreover, although Esty (2004) argues that the most important economic motive for using project finance is the reduction of agency conflicts inside project companies, the Eurotunnel case demonstrates that turning to IPO for equity capital for project finance can increase agency conflicts for project companies.

The Eurotunnel case is unique in that its share price data allows us to empirically measure the impacts of construction events on overall project risk and equity value. However, the atypical nature of Eurotunnel ownership structure (dispersed rather than concentrated equity ownership structure of typical project finance companies) also means the implications of this research paper could be limited to project finance cases seeking to raise equity capital through IPO, since IPO fundamentally changes the nature of project company's risk dynamics. As such, the limitations of this paper serve to highlight the need for further research in the areas of project risk measurement and project financing strategies for public-private partnerships.

\section{REFERENCES}

Abdul-Aziz, A. R., and Jahn Kassim, P. S. (2011) Objectives, success and failure factors of housing public-private partnerships in Malaysia. Habitat International, 35(1), 150-157.

Abednego, M. P., and Ogunlana, S. O. (2006). Good project governance for proper risk allocation in public-private partnerships in Indonesia. International Journal of Project Management, 24(7), 622-634. 
Ahadzi, M., and Bowles, G. (2004) Public-private partnerships and contract negotiations: an empirical study. Construction Management and Economics, 22(9), 967-978.

Akintoye, A., Taylor, C., and Fitzgerald, E. (1998) Risk analysis and management of Private Finance Initiative projects. Engineering, Construction and Architectural Management, 5(1), 9-21.

Akintoye, A., Hardcastle, C., Beck, M., Chinyio, E., and Asenova, D. (2003) Achieving best value in private finance initiative project procurement. Construction Management and Economics, 21(5), 461-470.

Beidleman, C. R., Fletcher, D., and Veshosky, D. (1990) On allocating risk: the essence of project finance. Sloan Management Review, 31 (Spring), 47-55.

Binder, J. J. (1998) The event study methodology since 1969. Review of Quantitative Finance and Accounting, 11(2), 111-137.

Bing, L., and Tiong, R. L. (1999). Risk management model for international construction joint ventures. Journal of construction engineering and management, 125(5), 377-384.

Bitsch, F., Buchner, A., and Kaserer, C. (2010) Risk, return and cash flow characteristics of infrastructure fund investments. EIB Papers, 15(1), 106-136.

Bordoli, D. W., and Baldwin, A. N. (1998) A methodology for assessing construction project delays. Construction Management \& Economics, 16(3), 327-337.

Brown, S. J., and Warner, J. B. (1985) Using daily stock returns: the case of event studies. Journal of Financial Economics, 14(1), 3-31

Campbell, J.Y., Lo, A.W., and MacKinlay, A.C. (1997) The Econometrics of Financial Markets, Princeton University Press, NJ, US.

Carrillo, P. M., Robinson, H. S., Anumba, C. J., and Bouchlaghem, N. M. (2006) A knowledge transfer framework: The PFI context. Construction Management and Economics, 24(10), 1045-1056.

Chang, C. Y., and Ive, G. (2007) The hold-up problem in the management of construction projects: A case study of the Channel Tunnel. International Journal of Project Management, 25(4), 394-404.

Chen, C., and Messner, J. I. (2005) An investigation of Chinese BOT projects in water supply: a comparative perspective. Construction management and economics, 23(9), 913-925.

Chen, N.F., Roll, R., and Ross, S.A. (1986) Economic forces and the stock market. Journal of Business, 59(3), 383-403

Chowdhury, A. N., Chen, P. H., and Tiong, R. L. (2011) Analysing the structure of public-private partnership projects using network theory. Construction Management and Economics, 29(3), 247-260.

Cox, I. D., Morris, J. P., Rogerson, J. H., and Jared, G. E. (1999) A quantitative study of post contract award design changes in construction. Construction Management \& Economics, 17(4), 427-439.

Dulaimi, M. F., Alhashemi, M., Ling, F. Y. Y., and Kumaraswamy, M. (2010) The execution of publicprivate partnership projects in the UAE. Construction Management and Economics, 28(4), 393-402.

Esty, B.C. (2004) Why study large projects? An introduction to research on project finance. European Financial Management, 10(2), 213-224.

Esty, B.C. and Christoy, I.L. (2002) An Overview of Project Finance. Harvard Business School Publishing, Boston.

Nevitt, P. and Fabozzi, F. (2000) Project Financing, 7th ed. Euromoney Books, London, UK. 
Fabozzi, F. J., Neave, E.H., and Zhou, G. (2012) Financial Economics, John Wiley \& Sons, Inc., NJ, USA.

Finnerty, J.D. (2007). Project Financing: Asset-Based Financial Engineering. John Wiley \& Sons, Inc., Hoboken, NJ, USA.

Flyvbjerg, B., N. Bruzelius and W. Rothengatter (2003) Megaprojects and Risk: an Anatomy of Ambition, Cambridge University Press, NY, US.

Han, S. H., and Diekmann, J. E. (2001) Approaches for making risk-based go/no-go decision for international projects. Journal of Construction Engineering and Management, 127(4), 300-308.

Harris, C. (2003) Private participation in infrastructure in developing countries: trends, impacts and policy lessons. World Bank Publications, Washington, D.C., USA.

Hastak, M., and Shaked, A. (2000) ICRAM-1: Model for international construction risk assessment. Journal of Management in Engineering, 16(1), 59-69.

Henjewele, C., Sun, M., and Fewings, P. (2011) Critical parameters influencing value for money variations in PFI projects in the healthcare and transport sectors. Construction Management and Economics, 29(8), 825-839.

Huseby, A.B. and Skogen, S. (1992) Dynamic risk analysis: The dynrisk concept. International Journal of Project Management, 10(3), 160-164.

Jablonowski, M. (1994) Fuzzy risk analysis: using AI systems. AI expert, 9(12), 38-41.

Jeljeli, M. N., and Russell, J. S. (1995) Coping with uncertainty in environmental construction: decisionanalysis approach. Journal of construction engineering and management, 121(4), 370-380.

Jensen, M.C. and Meckling, W.H. (1976) Theory of the firm: Managerial behavior, agency costs and ownership structure. Journal of Financial Economics, 3(4), 305-360.

Kleimeirer, S. and Megginson, W.L. (2000) Are project finance loans different from other syndicated credits? Journal of Applied Corporate Finance, 13(1), 75-87.

Lafontaine F. and Slade, M. (2007) Vertical integration and firm boundaries: the evidence. Journal of Economic Literature, 45(3), 629-685.

Lam, K. C., and Chow, W. S. (1999). The significance of financial risks in BOT procurement. Building Research \& Information, 27(2), 84-95.

Leiringer, R. (2006) Technological innovation in PPPs: incentives, opportunities and actions, Construction Management and Economics, 24(3), 301-308

Li, B., Akintoye, A., Edwards, P. J., and Hardcastle, C. (2005) Critical success factors for PPP/PFI projects in the UK construction industry. Construction management and economics, 23(5), 459-471.

Lianyu, C., and Tiong, R. L. (2005) Minimum feasible tariff model for BOT water supply projects in Malaysia. Construction Management and Economics, 23(3), 255-263.

Lintner, J. (1965) The valuation of risk assets and the selection of risky investments in stock portfolios and capital budgets, Review of Economics and Statistics, 47 (1), 13-37.

Liu, J., and Cheah, C. Y. (2009) Real option application in PPP/PFI project negotiation. Construction Management and Economics, 27(4), 331-342.

Macher, J. T. and Richman, B.D. (2008) Transaction cost economics: An assessment of empirical research in the social sciences. Business and Politics, 10(1), 1-63. 
Mackinlay A. C. (1997) Event studies in economics and finance. Journal of Economic Literature, 35(1), 13-39.

Masten, S., Meehan, J., and Snyder, E. (1991) The Costs of organization. Journal of Law, Economics, and Organization, 7(1): 1-25.

Merna, T., Chu, Y., and Al-Thani, F.F. (2010) Project Finance in Construction: A Structured Guide to Assessment, Wiley-Blackwell, Oxford, UK.

Merton R. (1973) An intertemporal capital asset pricing model. Econometrica, 41(5), 867-887.

Mulholland, B., and Christian, J. (1999) Risk assessment in construction schedules. Journal of Construction Engineering and Management, 125(1), 8-15.

Mustafa, M. A., and Al-Bahar, J. F. (1991). Project risk assessment using the analytic hierarchy process. Engineering Management, IEEE Transactions on, 38(1), 46-52.

Ozdoganm, I. D., and Birgonul, M. T. (2000) A decision support framework for project sponsors in the planning stage of build-operate-transfer (BOT) projects. Construction Management \& Economics, 18(3), 343-353.

Raisbeck, P. (2008) Perceptions of architectural design and project risk: understanding the architects' role in a PPP project. Construction Management and Economics, 26(11), 1145-1157.

Raisbeck, P., Duffield, C., and Xu, M. (2010) Comparative performance of PPPs and traditional procurement in Australia. Construction Management and Economics, 28(4), 345-359.

Roumboutsos, A., and Anagnostopoulos, K. P. (2008) Public-private partnership projects in Greece: risk ranking and preferred risk allocation. Construction Management and Economics, 26(7), 751-763.

Ross, S. A. (1976) The arbitrage theory of capital asset pricing, Journal of Economic Theory, 13(3), 341360.

Schaufelberger, J. E., and Wipadapisut, I. (2003) Alternate financing strategies for build-operate-transfer projects. Journal of construction engineering and management, 129(2), 205-213.

Shan, L., Garvin, M. J., and Kumar, R. (2010) Collar options to manage revenue risks in real toll

public-private partnership transportation projects. Construction Management and Economics, 28(10),

1057-1069.

Sharpe, W.F. (1964) Capital asset prices: A theory of market equilibrium under conditions of risk, Journal of Finance, 19 (3), 425-442.

Songer, A. D., Diekmann, J., and Pecsok, R. S. (1997) Risk analysis for revenue dependent infrastructure projects. Construction Management \& Economics, 15(4), 377-382.

Tabish, S. Z. S., and Jha, K. N. (2011) Identification and evaluation of success factors for public construction projects. Construction Management and Economics, 29(8), 809-823.

Tah, J. H. M., and Carr, V. (2000) A proposal for construction project risk assessment using fuzzy logic. Construction Management \& Economics, 18(4), 491-500.

Tang, L., Shen, Q., and Cheng, E.W.L. (2010) A review of studies on Public-Private Partnership projects in the construction industry. International Journal of Project Management, 28(7), 683-694

Thomas, A. V., Kalidindi, S. N., and Ananthanarayanan, K. A. B. T. (2003) Risk perception analysis of BOT road project participants in India. Construction Management and Economics, 21(4), 393-407. 
Thomas, A. V., Kalidindi, S. N., and Ganesh, L. S. (2006) Modelling and assessment of critical risks in BOT road projects. Construction Management and Economics, 24(4), 407-424.

Vazquez, F., and Allen, S. (2004) Private sector participation in the delivery of highway infrastructure in Central America and Mexico. Construction Management \& Economics, 22(7), 745-754.

Wang, S. Q., Tiong, R. L., Ting, S. K., and Ashley, D. (2000) Evaluation and management of foreign exchange and revenue risks in China's BOT projects. Construction Management \& Economics, 18(2), 197-207.

Wibowo, A. (2005) Estimating general threshold traffic levels of typical build, operate, and transfer toll road projects in Indonesia. Construction Management and Economics, 23(6), 621-630.

Williamson, O.E. (1985) The theory of the firm as governance structure: from choice to contract. The Journal of Economic Perspectives, 16(3), 171-195.

Woodward, D. G. (1995) Use of sensitivity analysis in build-own-operate-transfer project evaluation. International Journal of Project Management, 13(4), 239-246.

Xenidis, Y., and Angelides, D. (2005) The financial risks in build-operate-transfer projects. Construction

Management and Economics, 23(4), 431-441.

Ye, S., and Tiong, R. L. (2000) NPV-at-risk method in infrastructure project investment evaluation. Journal of Construction Engineering and Management, 126(3), 227-233.

Ye, S., and Tiong, R. L. (2003) Tariff adjustment frameworks for privately financed infrastructure projects. Construction Management and Economics, 21(4), 409-419.

Ye, S., and Tiong, R. L. (2003) The effect of concession period design on completion risk management of BOT projects. Construction Management and Economics, 21(5), 471-482.

Zayed, T. M., and Chang, L. M. (2002). Prototype model for build-operate-transfer risk assessment. Journal of Management in Engineering, 18(1), 7-16. 
Figure 1: Eurotunnel Project Structure

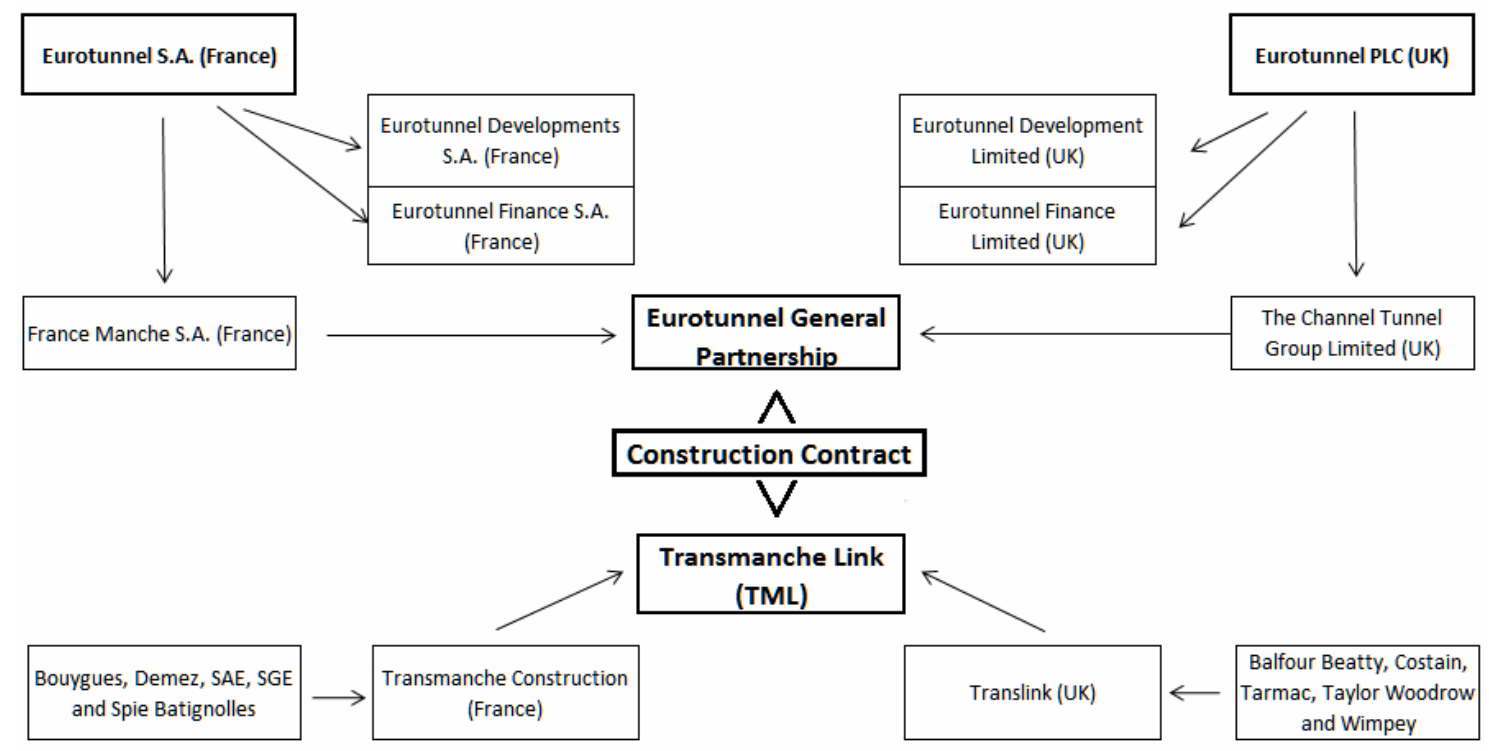

Table 1: Dispute Event Chronology

\begin{tabular}{|c|c|c|c|}
\hline Event Dates & Title of Announcement & Source & Disputes \\
\hline (1) 12 Jan. 1990 & "Deal Cuts Risk of Channel Tunnel Overruns" & Financial Times & Event \#1 \\
\hline (2) 10 Feb.1991 & "Eurotunnel Costs Set to Soar After Ruling" & Independent & Event \#2 \\
\hline (3) 30 Mar. 1992 & $\begin{array}{l}\text { "Dispute Panel Rules Eurotunnel Should Treble } \\
\text { Monthly Payment to Meet TML's Expenses" }\end{array}$ & Evening Standard & Event \#3 \\
\hline (4) 5 Oct. 1992 & "Opening Date Delay Adds to Worries" & Evening Standard & Event \#4 \\
\hline (5) 29 Mar. 1993 & "1bn Shortfall as Tunnel Hits New Delay" & The Guardian & Event \#5 \\
\hline (6) 28 Jul. 1993 & $\begin{array}{l}\text { "Eurotunnel and TML Reached Agreement about } \\
\text { Interim Payment" }\end{array}$ & The Times & Event \#6 \\
\hline (7) 6 Apr. 1994 & $\begin{array}{l}\text { "Settlement of } £ 1.14 \text { bn Payment from Eurotunnel to } \\
\text { TML" }\end{array}$ & $\begin{array}{l}\text { Financial Times } \\
\text { Evening Standard }\end{array}$ & Event \#7 \\
\hline
\end{tabular}


Table 2: Cumulative Abnormal Returns Using Market Model, CAPM, ICAPM, and APT

\begin{tabular}{|c|c|c|c|c|c|c|c|}
\hline EVENTS & Event \#1 & Event \#2 & Event \#3 & Event \#4 & Event \#5 & Event \#6 & Event \#7 \\
\hline EVENT DATES & $12 / 1 / 1990$ & $10 / 2 / 1991$ & $30 / 03 / 1992$ & $5 / 10 / 1992$ & 29/03/1993 & 28/07/1993 & 6/4/1994 \\
\hline $\begin{array}{c}\text { EVENT } \\
\text { WINDOW }\end{array}$ & $\begin{array}{c}\text { Market } \\
\text { Model AR } \\
\end{array}$ & $\begin{array}{c}\text { Market } \\
\text { Model AR }\end{array}$ & $\begin{array}{c}\text { Market } \\
\text { Model AR }\end{array}$ & $\begin{array}{c}\text { Market } \\
\text { Model AR }\end{array}$ & $\begin{array}{c}\text { Market } \\
\text { Model AR }\end{array}$ & $\begin{array}{c}\text { Market } \\
\text { Model AR }\end{array}$ & $\begin{array}{c}\text { Market } \\
\text { Model AR } \\
\end{array}$ \\
\hline-15 & 0.00 & 0.03 & 0.00 & 0.04 & 0.00 & 0.00 & 0.01 \\
\hline-14 & 0.03 & 0.04 & -0.01 & -0.01 & 0.02 & 0.00 & -0.01 \\
\hline-13 & 0.01 & 0.02 & 0.03 & 0.01 & 0.01 & -0.02 & 0.00 \\
\hline-12 & -0.03 & 0.03 & 0.00 & 0.02 & 0.00 & -0.01 & 0.01 \\
\hline-11 & 0.01 & 0.05 & 0.00 & 0.02 & -0.01 & 0.01 & -0.01 \\
\hline-10 & 0.01 & -0.03 & -0.01 & -0.03 & 0.01 & 0.01 & -0.01 \\
\hline-9 & 0.04 & -0.01 & -0.02 & 0.02 & 0.01 & 0.00 & 0.00 \\
\hline-8 & 0.04 & 0.03 & 0.00 & -0.01 & 0.01 & 0.00 & 0.00 \\
\hline-7 & 0.04 & -0.01 & 0.01 & 0.01 & -0.02 & 0.01 & 0.02 \\
\hline-6 & 0.07 & 0.02 & 0.01 & 0.03 & -0.01 & -0.01 & -0.01 \\
\hline-5 & -0.04 & 0.02 & -0.01 & 0.00 & 0.00 & 0.02 & -0.01 \\
\hline-4 & -0.02 & 0.04 & 0.00 & -0.02 & 0.02 & 0.00 & -0.01 \\
\hline-3 & 0.03 & -0.01 & 0.02 & 0.03 & -0.01 & 0.00 & 0.00 \\
\hline-2 & -0.01 & -0.02 & 0.02 & 0.01 & 0.01 & 0.00 & 0.00 \\
\hline-1 & -0.02 & -0.01 & 0.01 & -0.03 & 0.02 & 0.05 & -0.02 \\
\hline 0 & 0.01 & -0.05 & -0.06 & -0.12 & 0.01 & 0.02 & 0.01 \\
\hline 1 & -0.02 & 0.02 & 0.02 & -0.05 & -0.04 & -0.02 & -0.02 \\
\hline 2 & -0.01 & -0.01 & 0.03 & 0.02 & -0.03 & -0.02 & -0.01 \\
\hline 3 & 0.03 & -0.02 & 0.00 & 0.00 & 0.00 & -0.01 & 0.01 \\
\hline 4 & -0.02 & 0.00 & 0.00 & 0.00 & -0.02 & 0.01 & 0.00 \\
\hline 5 & 0.03 & -0.01 & -0.01 & 0.02 & 0.03 & 0.02 & 0.01 \\
\hline 6 & 0.01 & -0.01 & 0.03 & 0.01 & 0.00 & 0.02 & 0.01 \\
\hline 7 & -0.01 & -0.02 & -0.02 & -0.01 & 0.00 & 0.01 & 0.02 \\
\hline 8 & -0.02 & -0.01 & -0.02 & -0.01 & 0.02 & -0.02 & -0.02 \\
\hline 9 & 0.01 & 0.02 & -0.08 & 0.00 & -0.01 & 0.01 & -0.02 \\
\hline 10 & -0.01 & 0.03 & -0.04 & -0.01 & -0.01 & 0.01 & -0.04 \\
\hline 11 & 0.00 & 0.00 & -0.03 & 0.01 & 0.00 & 0.00 & -0.01 \\
\hline 12 & 0.02 & 0.04 & -0.01 & -0.02 & 0.00 & 0.00 & -0.05 \\
\hline 13 & -0.01 & -0.02 & 0.01 & -0.01 & -0.02 & 0.00 & 0.04 \\
\hline 14 & 0.00 & 0.00 & -0.01 & -0.01 & -0.01 & -0.01 & 0.01 \\
\hline 15 & 0.06 & 0.02 & 0.00 & 0.01 & -0.04 & -0.01 & 0.03 \\
\hline $\begin{array}{r}\text { Market Model } \\
\text { Cumulative AR }\end{array}$ & $0.21 *$ & $0.18 *$ & $-0.16 *$ & $-0.08 *$ & $-0.06 *$ & $0.07 *$ & $-0.10 *$ \\
\hline SD of Regression & 0.03 & 0.03 & 0.02 & 0.03 & 0.02 & 0.02 & 0.02 \\
\hline $\begin{array}{c}\text { Ratio of } \\
\text { CAR/Predicted } \\
\text { Returns }\end{array}$ & 16.0 & 13.6 & 12.2 & 6.5 & 4.8 & 5.6 & 8.1 \\
\hline CAPM & $0.21 *$ & 0.18* & $-0.16 *$ & $-0.08 *$ & $-0.06 *$ & $0.07 *$ & $-0.11 *$ \\
\hline ICAPM & $0.16 *$ & $0.15 *$ & $-0.17 *$ & $-0.08 *$ & $-0.04 *$ & $0.09 *$ & $-0.08 *$ \\
\hline APT & $0.14 *$ & 0.13* & $-0.2 *$ & $-0.09 *$ & $-0.02 *$ & $0.07 *$ & $-0.08 *$ \\
\hline
\end{tabular}

Normal return is calculated using $\alpha_{1}+\alpha_{2} R_{m t}+\varepsilon_{t}$ as the market model; $R_{f}+\alpha_{1}+\left(R_{m t}-R_{f}\right) \alpha_{2}+\varepsilon_{t}$ for CAPM model; $R_{f}+\alpha_{1}+\alpha_{2}\left(R_{m t}-R_{f}\right)+\alpha_{3}\left(R_{\text {longt }}-R_{f}\right)+\varepsilon_{t}$ for ICAPM mode; and $\alpha_{1}+\alpha_{2} R_{m t}+\alpha_{3} R_{\text {indt }}+\alpha_{4} R_{G \text { inf } t}+\alpha_{5} R_{\text {ind } \inf t}+\alpha_{6} R_{\text {employt }}+\alpha_{7}\left(R_{\text {longt }}-R_{f}\right)+\varepsilon_{t}$ for APT model.

Cumulative $A R(C A R)$ is the cumulative abnormal return over the event window. SD of regression is the sample standard deviation of the regression using market model, which can be used to test the significance of the CARs. Ratio of CAR/Predicted returns is another way to look at the significance of the CARs. * indicates significance at the $1 \%$ level. Event window is the days relative to the announcement date. 
Figure 2: Stock Volatility of Eurotunnel Measured by 12 Month Rolling Standard Deviation

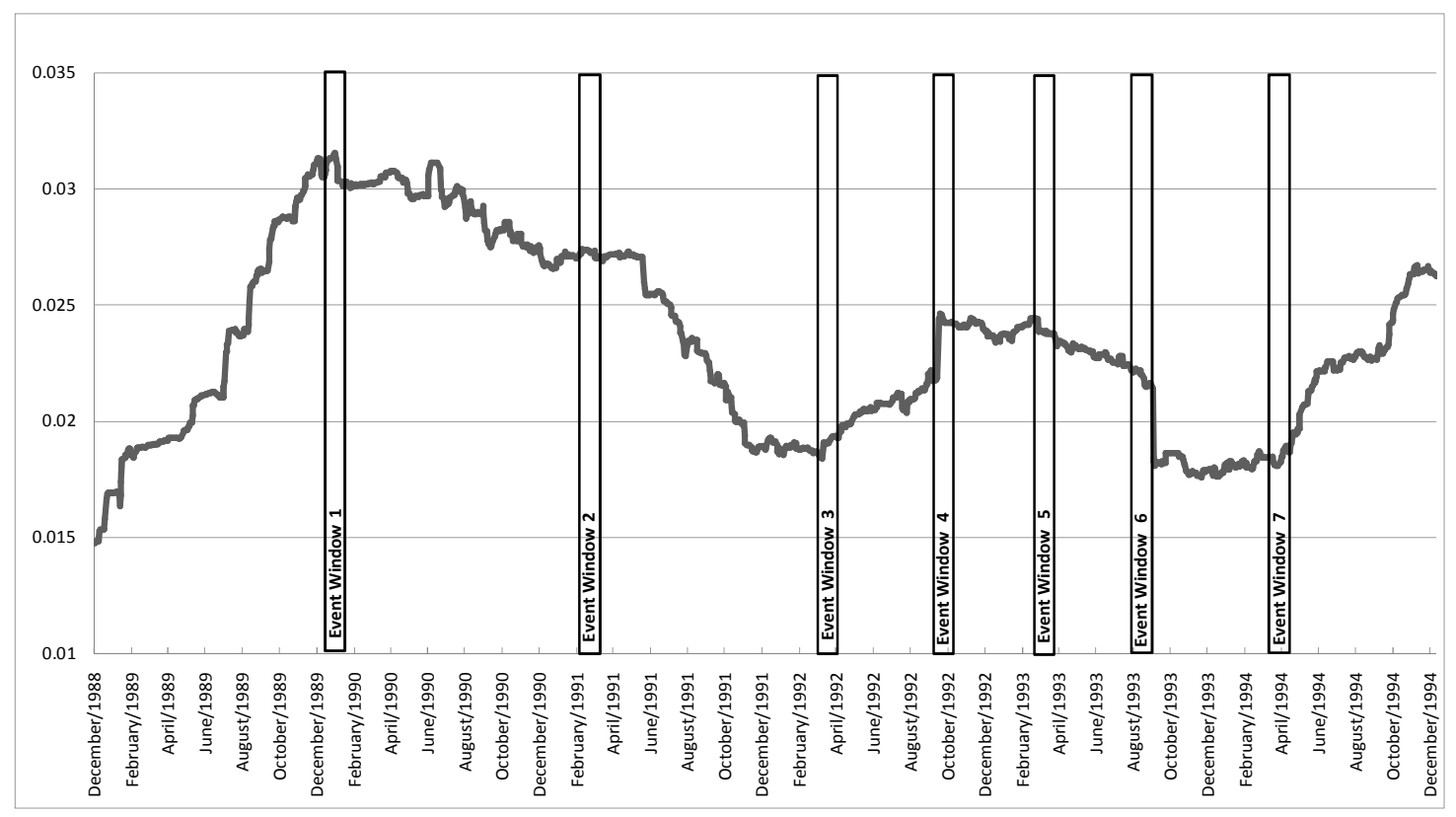

